\title{
Effects of Dietary Natural Clay Zeolite Supplementation on Growth Performance, Hematological Parameters and Body Composition of Nile Tilapia, oreochromis niloticus l. Fingerlings \\ Khaled M. Nssar ${ }^{1}$, Mohamed K. Ibrahim ${ }^{1}$, Magdy A. Soltan ${ }^{1}$, Mohamed S. Hassaan ${ }^{2}$ \\ ${ }^{1}$ Animal production department, Faculty of Agriculture, Benha University. \\ ${ }^{2}$ Aquaculture Division, Fish Nutrition Research Laboratory, National Institute of Oceanography and Fisheries (NIOF), Egypt \\ Corresponding author: Khaled.811@Yahoo.Com
}

\begin{abstract}
A feeding study was conducted to investigate the effect of dietary supplementation of zeolite (silicate clay) on growth performance, digestive enzymes, immunity and gut bacteria count of Nile tilapia, Oreochromis niloticus (L.) fingerlings. Three isonitrogenous $(300 \mathrm{~g} / \mathrm{kg}$ crude protein) and isocaloric (19.45 MJ/kg gross energy) diets were formulated. Each diet was supplemented with zeolite at levels; 0 (control), 5 and $10 \mathrm{~g} / \mathrm{kg}$ diet. After 84 days of feeding trial, the highest weight gain, specific growth rate, protein efficiency ratio and the best feed conversion ratio were recorded in fish fed either 5 or $10 \mathrm{~g} / \mathrm{kg}$ diet zeolite. The addition of zeolite improved significantly hematocrit, hemoglobin, red blood cells count, and white blood cells compared with control diet. In addition, the lowest activities of serum alanine and aspartate aminotransferase and alkaline phosphatase were observed in fish fed diets supplemented with $10 \mathrm{~g} / \mathrm{kg}$ diet zeolite. No significant differences were found in chemical composition of fish fed treatment diets. Results of this study indicated that the addition of zeolite as feed additive enhanced the growth, feed utilization and hematology and blood biochemistry of Nile tilapia.
\end{abstract}

Key words: zeolite, Nile tilapia, biochemistry, feed utilization.

\section{Introduction}

In last decades, aquaculture industry has developed rapidly in many countries. The aquaculture production improves by $15 \%$ annually, and is predicted to sustainability to grow fast in future (Hassaan et al., 2018). The sustainability of aquaculture development is dependent on the availability of quality and cheap feed stuffs. Any decrease in costs of feed would have a direct positive effect on profitability of aquaculture (Francis et al. 2005; Henry \& Alexis 2009). The feed additives improve the immunity, productivity and economic efficiency of fish via its improvement growth performance and feed utilization of the fish ( $\mathrm{Hu}$ et al., 2008; Yildirım et al., 2009).

Silicates (clay minerals) are arranged in threedimensional structures to create interconnecting channels to bind the specific molecules (Slamova et al., 2011). Hence, these clay minerals are regarded as effective materials to prevent or decrease the negative effects of toxic compounds. Zeolites, a kind of natural clay, are crystalline, hydrated aluminosilicates of alkali and alkaline earth cations, and have infinite three-dimensional structures (Mumpton, 1999). It is used as an additive in fish feeds and livestock or filler due to their detoxifying and nutrient absorption and growth enhancing features (Eya et al., 2008; Mumpton, 1999). As an unconventional feed additive, several studies have confirmed the decontamination properties of clays minerals against mycotoxins (Phillips et al., 2009; Zychowski et al., 2013). The adsorption capacity of any clay is relied on their fine structure, surface properties and exchangeable ions (Vondruskova et al., 2010). Previous studies indicated that the addition of clay minerals as clinoptilolite, bentonite and modernite could be improved the growth performance, feed utilization and blood profile of fish ( $\mathrm{Hu}$ et al., 2008; Yildirım et al., 2009; Ayoola, 2016). On the other hand, Kany1lmaz \& Tekelioğlu (2009); Yiğit \& Demir (2011) reported that the zeolite supplementation has no effect on growth performance of fish. No reports were found on the effects of natural minerals "zeolite" on growth performance, hematology and chemical composition of Nile tilapia. Therefore, the present study was designed to evaluate the effects of zeolite as unconventionally feed additives on growth, hematology and chemical composition of Nile tilapia, Oreochromis niloticus fingerlings.

\section{Materials and Methods}

\section{Experimental design and culture technique}

Nile tilapia, Oreochromis niloticus fingerlings were collected from private farm (Kafer Elsheakh Governorate, Egypt). Fish were acclimated to the experimental conditions as well as to adapt the artificial diet and conditions of the trail for ten days at the laboratory of fish Nutrition, National institute of Oceanography and fishers (NIOF) Egypt. During this period, tilapia was fed a control diet $(30 \%$ crude protein) at a rate of $3 \%$ of biomass, which offered of equal rations at 09:00 am and 3:00 pm (6 days/ week) for 2 weeks. After the acclimatization period fish were distributed randomly into the experimental concrete pond $\left(0.5 \mathrm{~m}^{3}\right.$ for each) representing the six 
treatments with three replicates. A 360 fish of tilapia mono-sex male fingerlings with average initial weight of $(7.6 \pm 0.06 \mathrm{~g})$ were used in this study. The daily diet was offered three times a day at (09:00, 12:00 and 15:00 h) equally. To adjusted the amount of feed fish were taken from each pond, weighed according to the changes in body weight through the experimental period. Daily, about one-third of water volume in each pond was daily replaced by new aerated freshwater after cleaning and removing of the accumulated excreta.

\section{Water quality}

To maintain the optimal range of water criteria of tilapia water temperature, dissolved oxygen, $\mathrm{pH}$, and total ammonia were monitored during the study. Water temperature was monitored daily at $13.00 \mathrm{~h}$ using a mercuric thermometer suspended at $30 \mathrm{~cm}$ depth. Dissolved oxygen (DO) was recorded at 09.00 $\mathrm{h}$ by using YSI model 56 oxygen meter (YSI Company, Yellow Springs Instrument, Yellow Springs, Ohio, USA) and $\mathrm{pH}$ at $09.00 \mathrm{~h}$ measured by using $\mathrm{pH}$ meter (Orion $\mathrm{pH}$ meter, Abilene, Texas, USA). Total ammonia was estimated two times a week following the methods of APHA (1985). The water temperature was $26.17 \pm 0.8^{\circ} \mathrm{C}$ : dissolved oxygen, $5.6 \pm 0.8 \mathrm{mg} \mathrm{L}^{-1}$ : total ammonia, $0.18 \pm 0.12$ $\mathrm{mg} \mathrm{L}^{-1}$ and $\mathrm{pH} 8.52 \pm 0.3$ and there was no mortality during the entire experimental period. All water criteria of this experiment were apparently satisfactory and fell under the optimal standards defined for nutritional evaluations in Nile tilapia (Boyd, 1990).

\section{Formulation of experimental diets}

Three isonitrogenous (300 $\mathrm{g} \mathrm{kg}^{-1}$ crude protein) and isolipidic $19.45 \mathrm{MJ} \mathrm{kg}^{-1}$ gross energy) diets were formulated (Table 1) in this feeding trial. The control diet contained no added zeolite. Other two diets were supplemented with 5 and $10 \mathrm{~g} \mathrm{~kg}^{-1}$ zeolite per diet, respectively. Natural clay minerals (Zeolite) was supplied from Research Institute of land, Agricultural Research Center Cairo, Egypt. The ingredients were ground into fine powder through $200 \mu \mathrm{m}$ mesh. All the ingredients were thoroughly mixed with soybean oil, and then the mixture was passed through a laboratory pellet mill (2-mm die; California Pellet Mill, San Francisco, CA, USA) at the National Institute of Oceanography and Fisheries, Cairo Governorate, Egypt, the temperature of pellets in this stage did not exceed $40{ }^{\circ} \mathrm{C}$. Diets were dried in opened air $\left(35^{\circ} \mathrm{C}\right)$, then packed in cellophane bags and stored at $-20^{\circ} \mathrm{C}$ until diets used.

Table 1. Composition and proximate analysis of the basal diet ( $\mathrm{g} / \mathrm{kg}$ dry matter)

\begin{tabular}{llll}
\hline Ingredients & Control & $5 \mathrm{~g} / \mathrm{kg}$ zeolite & $10 \mathrm{~g} / \mathrm{kg}$ zeolite \\
\hline Fish meal & 150 & 150 & 150 \\
Soybean meal & 380 & 380 & 380 \\
Yellow corn & 240 & 240 & 240 \\
Wheat bran & 150 & 145 & 140 \\
Soybean oil & 40 & 40 & 40 \\
Vitamins and minerals ${ }^{1}$ & 20 & 20 & 20 \\
Zeolite & 0 & 5 & 10 \\
Proximate analysis $\left(\mathrm{g} \mathrm{kg}^{-1}\right.$ dry matter basis) & & & \\
Dry matter & 90.02 & 91.10 & 91.56 \\
Crude protein & $30 . .61$ & 29.80 & 29.23 \\
Lipids & 7.09 & 6.89 & 5.71 \\
Ash & 7.45 & 7.13 & 7.15 \\
Total carbohydrate & 55.48 & 56.27 & 57.95 \\
Gross energy $\left(\mathrm{MJ} \mathrm{kg}^{-1}\right)^{3}$ & 19.80 & 19.70 & 19.09 \\
\hline
\end{tabular}

${ }^{1}$ Vitamins and minerals mix: MnSO4, 40 mg; MgO, 10 mg; K2SO4, 40 mg; ZnCO3, 60 mg; KI, 0.4 mg; CuSO4, 12 mg; Ferric citrate, $250 \mathrm{mg}$; Na2SeO3, $0.24 \mathrm{mg}$; Co, $0.2 \mathrm{mg}$; retinol, $40000 \mathrm{IU}$; cholecalciferol, $4000 \mathrm{IU}$; $\alpha$-tocopherolacetate, $400 \mathrm{mg}$; menadione, $12 \mathrm{mg}$; thiamine, $30 \mathrm{mg}$; riboflavin, $40 \mathrm{mg}$; pyridoxine, $30 \mathrm{mg}$; cyanocobalamin, $80 \mathrm{mcg}$; nicotinic acid, $300 \mathrm{mg}$; folic acid, $10 \mathrm{mg}$; biotin, $3 \mathrm{mg}$; pantothenic acid, $100 \mathrm{mg}$; inositol, $500 \mathrm{mg}$; ascorbic acid, $500 \mathrm{mg}$.

${ }^{2}$ Total carbohydrate $=100-($ crude protein + lipid + ash) .

${ }^{3}$ Calculated using gross calorific values of $23.63,39.52$ and $17.15 \mathrm{KJ} \mathrm{g}^{-1}$ for protein, fat and carbohydrate, respectively according to Brett (1973)

\section{Growth performance and feed utilization parameters}

Records of live body weight ( $\mathrm{g}$ ) was measured in all experimental fish for each pond and registered every 14 days (two weeks) during the experimental period. Growth performance and feed utilizationparameters were measured by using the following equations:
Weight gain $(\mathrm{WG})=$ final weight $(\mathrm{g})$ - initial weight (g)

Specific growth rate (SGR): it is one of the most important methods of growth expression, which are related to time and estimated using the following equation. 
SGR $=\frac{\ln W 2-\ln W 1}{t} \times 100 ;$ Where: $\mathrm{Ln}=$ the natural $\log ;$ $\mathrm{W}_{1}=$ first fish weight; $\mathrm{W}_{2}=$ the following fish weight in grams; $\mathrm{t}=$ period in days.

Feed conversion ratio $(\mathrm{FCR})$ : FCR $=$ Feed ingested $(\mathrm{g}) /$ Weight gain $(\mathrm{g})$

Protein efficiency ratio (PER): PER= Weight gain $(\mathrm{g}) /$ Protein ingested $(\mathrm{g})$

\section{Sample collection}

At the termination of the experiment, four fish were randomly selected from each pond and anaesthetized with t-amyl alcohol, sacrificed, and homogenized in a blender for final whole-body proximate composition. The fish were pooled for each pond separately, ovendried, ground, and stored at $-20{ }^{\circ} \mathrm{C}$ for subsequent analysis of proximate analysis.

\section{Blood sampling and hematological and biochemical indices}

At the end of the experiment, blood was collected from the caudal vein of five fish in all treatments, then divided into two portions. The first one was collected with the anticoagulant $10 \%$ Ethylene diaminetetra acetate (EDTA) to estimate hematology parameters (hematocrit (Htc), haemoglobin ( $\mathrm{Hb})$, red blood cells (RBCs) and white blood cells (WBCs). Htc was determined according methods of Reitman and Frankel (1957), Hb was determined using haemoglobin kits which is a standardized procedure of the cyanomethemoglobin method. Total count of WBCs was estimated by the indirect method of Martins et al. (2004). The second portion of the blood was allowed to clot at $4{ }^{\circ} \mathrm{C}$ and centrifuged at $3,000 \mathrm{rpm}$ for $10 \mathrm{~min}$. The nonhemolyzed serum was collected to estimate the liver function activities. Serum aspartate aminotransferase (AST) and alanine aminotransferase (ALT) were measured according to the method described by Reitman and Frankel (1957).

\section{Chemical analysis of fish and experimental diets}

The proximate chemical composition of fish and diet samples were determined according to procedures of AOAC (1995). Dry matter (DM) was measured after drying the samples in an oven $\left(105^{\circ} \mathrm{C}\right)$ for $24 \mathrm{~h}$. Ash estimated by incineration at $550{ }^{\circ} \mathrm{C}$ for $12 \mathrm{~h}$. Crude protein was determined by micro-Kjeldhal method, $\mathrm{N} \% \times 6.25$ (using Kjeltechauto analyzer, Model 1030, Tecator, Höganäs, Sweden) and crude fat by Soxhlet extraction with diethyl ether $\left(40-60^{\circ} \mathrm{C}\right)$.

\section{Statistical analysis}

All collected data of this trial were analyzed by using the software SAS, version 6.03 (Statistical Analysis System 1993). One-way analysis of variance (One-way ANOVA) was used to determine whether significant variation existed between the treatments. When overall differences were found, differences between means were tested by Duncan's multiple range tests.

\section{Results}

\section{Growth parameters}

No mortalities were found throughout the experiment. The growth performance of Oreochromis niloticus fed the experimental diets is presented in Table 2. There were no significant differences in initial weights among the treatment groups; however, after 84 days the group fed the diet containing $10 \mathrm{~g} \mathrm{~kg}^{-1}$ zeolite had the highest final body weights, weight gain and specific growth rates (SGR). Feed intake in the present study increased significantly with increased levels of zeolite. Addition of zeolite to the feed also produced a better feed conversion ratio (FCR) and protein efficiency ratio (PER) with values significantly $(\mathrm{P}<0.05)$ higher than those in the diet un supplemented with zeolite (control), more specifically in the groups treated with $10 \mathrm{~g} \mathrm{~kg}^{-1}$ zeolite.

Table 2 Growth indices and nutrient utilization of $O$. niloticus after 84 days of feeding natural clay zeolite supplemented diets

\begin{tabular}{lllll}
\hline Items & Control & $5 \mathrm{~g} / \mathrm{kg}$ zeolite & $10 \mathrm{~g} / \mathrm{kg}$ zeolite & $\mathrm{SE}$ \\
\hline Initial body weight $(\mathrm{g})$ & 7.70 & 8.10 & 8.14 & 0.064 \\
Final body weight $(\mathrm{g})$ & $37.60^{\mathrm{b}}$ & $46.61^{\mathrm{a}}$ & $50.51^{\mathrm{a}}$ & 1.24 \\
Weight gain $(\mathrm{g})$ & $29.96^{\mathrm{b}}$ & $38.56^{\mathrm{a}}$ & $42.41^{\mathrm{a}}$ & 1.21 \\
Specific growth rate $(\%)$ & $1.88^{\mathrm{c}}$ & $2.08^{\mathrm{b}}$ & $2.17^{\mathrm{a}}$ & 0.04 \\
Feed intake $(\mathrm{g})$ fish $^{-1}$ & $37.14^{\mathrm{b}}$ & $43.07^{\mathrm{a}}$ & $45.67^{\mathrm{a}}$ & 2.49 \\
Feed conversion ratio & $1.24^{\mathrm{a}}$ & $1.12^{\mathrm{b}}$ & $1.07^{\mathrm{c}}$ & 0.12 \\
Protein efficiency ratio & $2.71^{\mathrm{c}}$ & $2.98^{\mathrm{b}}$ & $3.09^{\mathrm{a}}$ & 0.23 \\
\hline
\end{tabular}

Results were presented as means \pm SE of triplicate observations. Means in the same row with different superscript letters were significantly different at $\mathrm{p}<0.05$.

\section{Hematological parameters}

Table 3 shows the effect of zeolite addation on Nile tilapia hematological indices $\mathrm{Htc}, \mathrm{Hb}, \mathrm{RBC}$ and WBC counts. Htc, Hb, RBC and WBC counts were significantly $(\mathrm{P}<0.05)$ higher in the fish fed diet supplemented with zeolite (5 and $10 \mathrm{~g} \mathrm{~kg}^{-1}$ diet) compared with control. 
Table 3. Hematological parameters of $O$. niloticus after 84 days of feeding natural clay zeolite supplemented

\begin{tabular}{lllll}
\multicolumn{1}{c}{ diets } & \multicolumn{5}{c}{} & \\
\hline Items & Control & $5 \mathrm{~g} / \mathrm{kg}$ zeolite & $10 \mathrm{~g} / \mathrm{kg}$ zeolite & $\mathrm{SE}$ \\
\hline Hematocrit $(\%)$ & $23.85^{\mathrm{bc}}$ & $29.10^{\mathrm{a}}$ & $27.80^{\mathrm{a}}$ & 0.112 \\
Hemoglobin $(\mathrm{g} / \mathrm{dl})$ & $11.75^{\mathrm{ab}}$ & $12.25^{\mathrm{a}}$ & $12.50^{\mathrm{a}}$ & 0.131 \\
WBCs $\left(\times 10^{-3} \mathrm{~mm}^{-3}\right)^{1}$ & $79.50^{\mathrm{b}}$ & $91.50^{\mathrm{a}}$ & $92.31^{\mathrm{a}}$ & 3.01 \\
RBCs $\left(\times 10^{-3} \mathrm{~mm}^{-3}\right)^{2}$ & $1.845^{\mathrm{c}}$ & $2.27^{\mathrm{a}}$ & $2.81^{\mathrm{a}}$ & 0.007 \\
\hline
\end{tabular}

Results were presented as means \pm SE of triplicate observations. Means in the same row with different superscript letters were significantly different at $\mathrm{p}<0.05$.

${ }^{1}(\mathrm{WBCs})=$ white blood cell count, ${ }^{2}(\mathrm{RBCs})=$ red blood cell count.

Biochemical blood parameters

According to the results of the analysis, the fish that received the higher level of zeolite $(10 \mathrm{~g} \mathrm{~kg})$ exhibited significantly $(\mathrm{P}<0.05)$ lower AST, ALT and ALP activity compared with control (Table 4).

Table 4. Blood biochemical parameters of $O$. niloticus after 84 days of feeding natural clay zeolite supplemented diets

\begin{tabular}{lllll}
\hline Items & Control & $5 \mathrm{~g} / \mathrm{kg}$ zeolite & $10 \mathrm{~g} / \mathrm{kg}$ zeolite & $\mathrm{SE}$ \\
\hline $\mathrm{ALT}^{1}$ & $92.50^{\mathrm{c}}$ & $87.00^{\mathrm{d}}$ & $79.50^{\mathrm{e}}$ & 2.23 \\
$\mathrm{AST}^{2}$ & $14.50^{\mathrm{b}}$ & $12.50^{\mathrm{bc}}$ & $10.50^{\mathrm{c}}$ & 0.98 \\
$\mathrm{ALP}^{3}$ & $94.00^{\mathrm{b}}$ & $83.50^{\mathrm{b}}$ & $75.00^{\mathrm{d}}$ & 3.01 \\
\hline
\end{tabular}

Results were presented as means \pm SE of triplicate observations. Means in the same row with different superscript letters were significantly different at $\mathrm{p}<0.05$.

$\mathrm{ALT}^{1}=$ Alanine aminotransferase $\mathrm{AST}^{2}=$ Aspartate aminotransferase $; \mathrm{ALP}^{3}=$ Alkaline phosphatase

\section{Chemical composition of whole fish}

At the end of the experiment, supplementing the feed with zeolite did not have a significant $(\mathrm{P}>0.05)$ effect on dry matter, lipid, crude protein, or ash contents of the fish (Table 5).

Table 5. Chemical composition of $O$. niloticus after 84 days of feeding natural clay zeolite supplemented diets

\begin{tabular}{lllll}
\multicolumn{1}{c}{$\left(\mathrm{g} \mathrm{kg}^{-1}\right.$ wet basis $)$} & & & \\
\hline Items & Control & $5 \mathrm{~g} / \mathrm{kg}$ zeolite & $10 \mathrm{~g} / \mathrm{kg}$ zeolite & $\mathrm{SE}$ \\
\hline Dry matter & 272.17 & 277.02 & 278.34 & 0.084 \\
Crude protein & 158.25 & 159.21 & 159.98 & 0.181 \\
Lipid & 63.23 & 65.89 & 65.23 & 0.132 \\
Ash & 31.22 & 31.98 & 32.10 & 0.116 \\
\hline
\end{tabular}

Results were presented as means \pm SE of triplicate observations. Means in the same row with different superscript letters were significantly different at $\mathrm{p}<0.05$.

\section{Discussion}

The improvement in growth rate and feed efficiency of fish tilapia fed diet supplemented with 5 and $10 \mathrm{~g} \mathrm{~kg}$ zeolite may have been related to the concomitant improvements in apparent total tract nutrient digestibility and/or to a possible improvement in gut function and general health status. Obtained results are consistent with those revealed a positive effect of dietary clays on growth performance such as Obradović et al. (2006), Eya et al. (2008) and Danabas (2009) in rainbow trout and Khodanazary et al. (2013) in common carp. Likewise, Kany1lmaz et al., (2015) who showed that addition zeolite in tilapia diets enhanced growth and feed utilization compared to control. These results may be possibly due to the natural clay as a feed additive can reduce feed/nutrient waste (Ceulemans et al. 2009).

Hematological parameters are used as valuable biological indicators in response to dietary manipulations (Maheswaran et al. 2008). In the present study, hematological parameters of Nile tilapia were taken into account and significant differences were found among different dietary treatments. Higher red blood cell (RBC), Htc and $\mathrm{Hb}$ values were found in fish fed zeolite $10 \mathrm{~g} \mathrm{~kg}^{-1}$. Supplementation of natural earth mineral (Macsumsuk®) improved hematological parameters of Nile tilapia; however, excess supplementation could adversely affect the health of fish (Shahkar et al., 2015). This suggests that care should be taken to maintain the optimum supplementation level. In the present study, WBCs and their differential are increased by sericite supplementation in all treated diets compared to control diet. This increase could be related to increase non-specific or innate immunity as well as their count can be considered as an indicator of the health status of fish. Similarly, WBCs was significantly high when Channa striatus fed diet enriched with zeolite (Jawahar et al., 2016).

The activities of liver enzymes; ALT and AST are considered as indicators for hepatotoxicity and histopathological changes (Sheikhzadeh et al., 2017; Hassaan et al., 2018). In the current study, serum 
activities of ALT and AST were significantly improved by zeolite addation, which indicating that the dietary zeolite with different levels had no harmful effect on tilapia health, even though more histological studies are needed to demonstrate that. Similar findings were previously showed on common carp (Kanyılmaz \& Tekellioğlu, 2016) and rainbow trout (Sheikhzadeh et al., 2017) fed diets with different levels of zeolite. Serum proteins are useful for production more energy during stress conditions (detoxify the toxicant) to overcome this stress (Singh et al., 2010). The mechanism of dietary zeolite or any natural clays minerals effects on serum biochemical changes is not well-known; thus further studies are needed in this concern.

\section{References}

American Public Health Association. APHA. (1985) Standard methods for the examination of water and wastewater. American Public Health Association, American Water Works association, Water Environment Federation, Washington.

Andreeva, A. M.(1999).Structural and Functional Organization of the Albumin System of Fish Blood. Journal of ichthyology, 39(9), 788-794.

AOAC.(1995). In: Cunn, P.A. (Ed.), Official Methods of Analysis of the Association Official Analytical Chemists, vol. 1, 16th ed. AOAC International, Arlington, USA, p. 1298.

Ayoola, M.O. (2016). Application of dietary bentonite clay as feed additive on feed quality, water quality and production performance of African catfish (Clarias gariepinus). Ph.D., Faculty of Agri. Sciences, Stellenbosch University, $175 \mathrm{p}$.

Boyd,C. E. (1990). Water quality in Ponds for Aquaculture. Alabama Agric. Experiment Station, Auburn Univ., Alabama.

Brett, J. R. (1973). Energy expenditure of Sockeye salmon Oncorhynchus nerka, during sustained performance. J. of the Fish. Res. Board of Canada, 30: 1799 -1809.

Ceulemans, S.; Coutteau, P.; and Robles, R. (2009). Innovative feed additives improve feed utilization in Nile tilapia. Global aquaculture advocate. Adv, Nov/Dec. 63-65.

Coles, E.H. (1974). Plasma proteins. In: Veterinary clinical pathology, 2nd edition. W.B. Saunders Co., Philadelphia, Pennsylvania, USA, pp. 558560.

Danabas, D. (2009). Effects of different rates of zeolite (clinoptilolite) on some water parameters and growth and body composition of rainbow trout (Oncorhynchus mykiss Walbaum, 1792). Department of Fisheries, Institute of Naturel and Applied Sciences, University of Cukurova, 82.

Eya, J. C.; Parsons, A.; Haile, I.; and Jagidi, P. (2008). Effects of dietary zeolites (bentonite and mordenite) on the performance juvenile rainbow trout Onchorhynchus myskis. Australian Journal of Basic and Applied Sciences, 2(4), 961-967.

Francis, G.; Makkar, H. P.; and Becker, K. (2005). Quillaja saponins - a natural growth promoter for fish. Animal feed science and technology, 121(1-2), 147-157.

Hassaan, M. S.; Soltan, M. A.; Mohammady, E. Y.; Elashry, A. M.; El-Haroun, E. R.; and Davies, S. J. (2018b). Growth and physiological responses of Nile tilapia, Oreochromis niloticus fed dietary fermented sunflower meal inoculated with Saccharomyces cerevisiae and Bacillus subtilis. Aquaculture, 495, 592-601.

Henry, M.A.; and Alexis, M. N. (2009). Effects of in vitro lactoferricin and lactoferrin on the head kidney cells of European sea bass (Dicentrarchus labrax, L.). Veterinary immunology and immunopathology, 130(3-4), 236-242.

Henry, R.; Cannon, D.; Winkleman, J. (1974). Automated determination of serum and urine creatinine. Clinical chemistry, principles and techniques. New York: Harper and Row, 552-555.

Henry, R.J. (1964). Colorimetric determination of total protein. In: Clinical Chemistry. New York: Harper and Row Publ.

Hu,C.H.; Xu,Y.; Xia,M.S.; Xiong, L.; and Xu, Z.R. (2008). Effects of $\mathrm{Cu}^{2+}$-exchanged montmorillonite on intestinal microflora, digestibility and digestive enzyme activities of Nile tilapia. Aquaculture Nutrition, 14, 281-288.

Jawahar, S.; Nafar, A.; Vasanth, K.; Musthafa, M. S.; Arockiaraj, J.; Balasundaram, C.; and Harikrishnan, R. (2016). Dietary supplementation of Zeolite on growth performance, immunological role, and disease resistance in Channa striatus against Aphanomyces invadans. Fish and Shellfish Immunolology, 51, 161-169.

Kanyılmaz, M.; and Tekellioğlu, M. (2016). Effects of dietary zeolite levels on some blood parameters of Gilthead seabream (Sparus aurata) Juveniles. Journal of Aquaculture Engineering and Fisheries Research, 2(3), 119127.

Kanyılmaz, M.;Tekelioğlu, N.; Sevgili, H.;Uysal, R.; and Aksoy, A. (2015). Effects of dietary zeolite (clinoptilolite) levels on growth performance, feed utilization and waste excretions by gilthead sea bream juveniles (Sparus aurata). Animal Feed Science and Technology, 200, 66-75.

Khodanazary, A.; Boldaji, F.; Tatar, A.; and Dastar, B. (2013). Effects of dietary zeolite and perlite supplementations on growth and nutrient utilization performance, and some serum variables in common carp, (Cyprinus carpio). Turkish Journal of Fisheries and Aquatic Sciences, 13(3), 495-501. 
Maheswaran, R.; Devapaul, A.; Muralidharan, S.; Velmurugan, B.; and Ignacimuthu, S. (2008). Haematological studies of fresh water fish, Clarias batrachus (L.) exposed to mercuric chloride. IJIB. 2:49-54.

Mumpton, F. A. (1999). La roca magica: uses of natural zeolites in agriculture and industry. Proceedings of the National Academy of Sciences, 96(7), 3463-3470.

Obradović, S.; Adamović, M.; Vukašinović, M.; Jovanović, R.; and Levic, J. (2006). The application effects of natural zeolite in feed and water on production results of Oncorhynchus Mykiss (Walbaum). Mortality (the number of fish), 225, 153.

Phillips, T.D.; Marroquin, C.A.; Deng, Y.; Taylor, J.F.; Hallmark, C.T.; and Johnson, N.M. (2009). In vitro and in vivo characterization of mycotoxin-binding additives used for animal feeds in Mexico. Food Additives and Contaminants. A, 26, 733-743.

Reitman, A.; and Frankel, S. (1957). Determination of aspartat glutamic aminotransferase and alanin aminotansferase. American Journal of Clinical Pathology, 28: 56.

Shahkar, E.; Park, G.; Lee, D. M.; Kwak, S.; and Bai, S. C. (2015). Effects of dietary Macsumsuk® supplementation on growth performance, haematological parameters, disease resistance and body composition of juvenile Nile tilapia, Oreochromis niloticus L. Journal of Applied Animal Research, 43(2), 125-130.

Sheikhzadeh, N.; Kouchaki, M.; Mehregan, M.; Tayefi- Nasrabadi, H.; Divband, B.; Khataminan, M.; Oushani, A. K.; and Shabanzadeh, S. (2017). Influence of nanochitosan/zeolite composite on growth performance, digestive enzymes and serum biochemical parameters in rainbow trout (Oncorhynchus mykiss). Aquaculture Research, 48, 5955-5964.

Singh, A. P.; Singh, S.; Bhartiya, P.; and Yadav, K . (2010). Toxic effect of phorate on the serum biochemical parameters of snake headed fish Channa punctatus (Bloch). Advances in Bioresearch, 1(1), 177-181.

Slamova, R.; Trckova, M.; Vondruskova, H.; Zraly, Z.; and Pavlik, I. (2011). Clay minerals in anim. nutri. Applied Clay Science, 51, 395398.

Statistical Analysis system. (1993). SAS/STAT user Guide Release 6.03 Edition. SAS Institute Inc. Cary, North Carolina, USA.

Vondruskova, H.; Slamova, R.; Trckova, M.; Zraly, Z.; and Pavli, I. (2010). Alternatives to antibiotic growth promotors in prevention of diarrhea in weaned piglets: A review. Veterinary Medicine, 55, 199-224.

Wotton, I.; and Freeman, H. (1982). Microanalysis in medicinal biochemical. Churchill Livingstone, Edinburgh, London. 1982.

Yiğit, N.O.; and Demir, O. (2011). Klinoptilolit'in Gökkuşağı Alabalığı (Oncorhynchus mykiss) Yavrularının Büyümesi Üzerine Etkisi. Journal of Fisheries Science, 5, 213-218.

Yildirım, Ö.; Türker, A.; and Şenel, B. (2009). Effects of natural zeolite (Clinoptilolite) levels in fish diet on water quality, growth performance and nutrient utilization of Tilapia (Tilapia zillii) fry. Environmental Bulletin, 18, 1567-1571.

Zychowski, K. E.; Pohlenz, C.; Mays, T.; Romoser, A.; Hume, M.; Buentello, A.; and Phillips, T. D. (2013). The effect of NovaSil dietary supplementation on the growth and health performance of Nile tilapia (Oreochromis niloticus) fed aflatoxin-B1 contaminated feed. Aquaculture, 376, 117-123. 